\title{
The length of the lower limbs, the index of length and muscularity of the lower limbs, and the results of the "Timed Up and Go" test in school-age children - a pilot study
}

\author{
Długość kończyn dolnych, wskaźnik długości i umięśnienia kończyn dolnych \\ a wyniki testu „Timed Up and Go" u dzieci w wieku szkolnym - badanie pilotażowe
}

Lidia Perenc, Justyna Podgórska, Klaudia Skiba

Institute of Health Sciences, University of Rzeszow, Rzeszow, Poland

Director of the Institute: Lidia Perenc PhD, Prof. UR

Medical Studies/Studia Medyczne 2020; 36 (3): 181-188

DOI: https://doi.org/10.5114/ms.2020.99539

Key words: child, anthropometry, physical fitness.

Słowa kluczowe: dziecko, antropometria, sprawność fizyczna.

\begin{abstract}
Introduction: The authors were interested in whether the length of lower limbs and the index of the length and muscularity of lower limbs differentiates the "Timed Up and Go" test (TUG) results in school-aged children. The study is of a pilot nature. There is currently no table of norms for the TUG results in children.

Aim of the research: To examine whether the results of the TUG are differentiated by the length of lower limbs and indices of the length and muscularity of the lower limbs in school-aged children, and whether the anthropometric parameters mentioned are differentiated by age and gender.

Material and methods: The study group consisted of 31 school-aged children. For measuring anthropometric features body height, length of lower limbs (height of symphysion, iliospinale anterior, trochanterion), and the largest circumference of the shin at rest, an anthropometer and anthropometric tape were used, respectively. From the collected measurements, the following ratios were calculated: length and muscularity of lower limbs. Each participant was subjected to two measurements by means of the TUG. The average time taken for the TUG was calculated.

Results: There were no statistically significant positive correlations between the studied anthropometric parameters and the TUG results $(p>0.05)$. There were statistically significant correlations between the age and the length of the lower limbs $(p<0.001)$.

Conclusions: The TUG results are not differentiated by the studied anthropometric parameters. Age differentiates the length of lower limbs. There is a need to develop normative TUG values for children. Establishment of the TUG normative values is clinically significant for comparing physical function of healthy and disabled children.
\end{abstract}

\section{Streszczenie}

Wprowadzenie: Autorów zainteresowało, czy długość kończyn dolnych, wskaźnik długości kończyn dolnych i wskaźnik umięśnienia kończyn dolnych różnicuje wynik testu „Timed Up and Go” (TUG) u dzieci w wieku szkolnym. Przedstawione badanie ma charakter pilotażowy. Obecnie nie ma tabeli norm wyników testu TUG u dzieci.

Cel pracy: Zbadanie, czy wyniki testu TUG są zróżnicowane przez długość kończyn dolnych, wskaźniki długości i umięśnienia kończyn dolnych u dzieci w wieku szkolnym oraz czy wymienione parametry antropometryczne są zróżnicowane przez wiek i płeć.

Materiał i metody: Badaniami objęto grupę 31 dzieci w wieku szkolnym. Do pomiaru cech antropometrycznych: wysokości ciała, długości kończyn dolnych (wysokości symphysion, iliospinale anterior, trochanterion), największego obwodu goleni w spoczynku użyto odpowiednio antropometru i taśmy antropometrycznej. Z zebranych pomiarów obliczono wskaźniki proporcji: długości kończyn dolnych, umięśnienia kończyn dolnych. Każdy badany został poddany dwóm próbom testu TUG. Obliczono średni czas wykonania tego testu.

Wyniki: Nie stwierdzono statystycznie istotnych dodatnich korelacji między badanymi parametrami antropometrycznymi a wynikami testu TUG $(p>0,05)$. Wykazano statystycznie istotne zależności między wiekiem badanych a długością kończyn dolnych $(p<0,001)$.

Wnioski: Wynik testu TUG nie jest zróżnicowany przez badane parametry antropometryczne. Wiek różnicuje długość kończyn dolnych. Należy ustalić wartości normatywne wyników testu TUG u dzieci. Ich opracowanie ma istotne znaczenie kliniczne dla porównania sprawności fizycznej dzieci zdrowych i niepełnosprawnych. 


\section{Introduction}

Anthropometric methods are currently used in the medical, health, and physical culture sciences [1-3]. Today, morphological features, also known as anthropometric features, play a fundamental role in describing the silhouette and structure of the human body [1]. Their description includes height, width, and circumference measurements. The correctness of measuring the anthropometric feature is ensured by the correct starting position of the examined body, knowledge and correct use of anthropometric points located on the body, and the selection of appropriate measuring instruments $[2,4,5]$. When performing anthropometric measurements, the subject is obliged to assume a standard posture, i.e. upright, with lower limbs joined by heels, compact feet, and head in horizontal Frankfurt position [6]. To determine the height of the body (B-v), the length of the lower limbs, height of the symphysion (B-sy), iliospinale anterior (B-is), and trochanterion (B-tro) it is necessary to know the location of odd points located in the median plane: vertex (v), symphysion (sy), iliospinale anterior (is), and trochanterion (tro). The largest resting circumference of the shin is at the level of the surale point (sur). The measurement is made with relaxed lower leg muscles [1, 2, 7-9]. To assemble the above-mentioned measurement height, the investigator must be provided with an anthropometer. Anthropometric tape is used when measuring circumferences. The measurement accuracy in both cases is $1 \mathrm{~mm}$ [1]. Increasing body dimensions is characteristic of the growth process. The process of varying body proportions can be characterised by using proportion ratios, such as the length index of the lower limbs or the muscularity index of the lower limb (Table $1 \mathrm{C}$ ) [1]. Collecting quantitative data characterising the process of growth and differentiation of body proportions makes it possible to learn and describe human morphological development [7].

Motor development is another component of physical development - the child gradually acquiring and improving motor skills [10]. Movement capabilities of the human body differ significantly at individual stages of ontogenesis [11]. In order to evaluate children's motor development, measurements of their motor features are performed [12]. At school age, the ability to understand motor contents and competition is shaped. There is a desire to participate in physical education classes, and an increase in the ability to focus on the implementation of one specific activity, as well as the ability to initiate cyclical, systematic work on oneself. Then the so-called motor excellence is achieved. Therefore, a child reaching school age has easy learning and quickly masters movements of high difficulty and complex structure. This is a unique situation that is not met at any other stage of life and development [12-14]. A special motor skill is the ability to walk. Gait is a highly complicated and complex activity that develops with human ontogenetic development. Physiological gait requires interaction in the functioning of the muscular and skeletal systems, as well as uninterrupted control by the nervous system, while guaranteeing the lowest possible energy expenditure of the body [15-18]. The gait pattern undergoes constant, dynamic changes until skeletal maturation ends. It is believed that the length of the lower limbs, as well as neurological and motor maturity, have a significant impact on the development of children's gait [19]. Usually a fully mature gait can be observed already in 6-year-old children [20]. The main obstacle encountered by the child is to acieve motor coordination while maintaining balance in a standing position [19]. Abnormal gait is a sign of skeletal and nervous system damage [21].

"Timed Up and Go" (TUG) is a test that helps researchers assess balance-coordination capabilities [22]. Its modern version was developed by Diane Podsiadlo and Sandra Richardson in 1991 [9]. It is based on estimating the time needed for the subject to perform a specific motor task. The tested person is asked the following, in order: to get up from a sitting position, go through a previously measured length of $3 \mathrm{~m}$ with a steady, right for him/her pace, cross the end line of the mentioned distance, make a $180^{\circ}$ turn, and then return to the seat at the same pace and sit down $[23$, 24]. The reliability of the final result ensures a double test repetition. A timer is used to measure the time. The TUG is used primarily in research in the field of gerontology [25, 26], e.g. to assess the risk of falls, but also in paediatrics - to assess the physical fitness of patients suffering from cerebral palsy [27]. Due to the fact that the development of gait is affected by the length of the lower limbs, the researchers became interested in whether the length of the lower limbs differentiates the TUG results in the group of school children.

\section{Aim of the research}

Aim of the study to investigate whether the TUG results are differentiated by the length of the lower limbs, and indices of the length and muscularity of the lower limbs in school-age children, and whether the anthropometric parameters mentioned are differentiated by age and gender.

\section{Material and methods}

The study was conducted as part of the subject of the BA seminar. The research has not received any funding. It took place with the consent of the parents of the examined children, after prior consultation with the school's headmaster and student tutors, and after obtaining the consent of the Bioethical Committee of the University of Rzeszow (Decision number: 2018/05/7b).

The study was conducted among a group of 31 children who volunteered at a primary school in 
Table 1. Age and sex of the studied group and characteristics of the parameters tested

\begin{tabular}{|c|c|c|c|c|c|}
\hline \multicolumn{6}{|c|}{ A. Age of the studied group [years] } \\
\hline \multirow[t]{2}{*}{ Age [years] } & $\bar{x}$ & Me & Min. & Max. & SD \\
\hline & 8.58 & 9 & 7 & 12 & 1.20 \\
\hline \multicolumn{6}{|c|}{ B. Sex of the studied group } \\
\hline Sex & \multicolumn{2}{|r|}{$N$} & \multicolumn{3}{|c|}{$\%$} \\
\hline Girls & \multicolumn{2}{|r|}{15} & \multicolumn{3}{|c|}{48.39} \\
\hline Boys & \multicolumn{2}{|r|}{16} & \multicolumn{3}{|c|}{51.61} \\
\hline Total & \multicolumn{2}{|r|}{31} & \multicolumn{3}{|c|}{100.00} \\
\hline \multicolumn{6}{|c|}{ C. Formulas of indices } \\
\hline LL LI & & \multicolumn{4}{|c|}{ MI LL } \\
\hline $\mathrm{LLL} / \mathrm{BH} \times 100$ & & \multicolumn{4}{|c|}{ LRC S/LLL $\times 100$} \\
\hline \multicolumn{6}{|c|}{ D. Statistical characteristics $z$ of the parameters tested } \\
\hline Variable & $\bar{x}$ & Me & Min. & Max. & SD \\
\hline $\mathrm{BH}[\mathrm{cm}]$ & 132.52 & 133.00 & 115.00 & 156.00 & 11.59 \\
\hline RLLL $1[\mathrm{~cm}]$ & 71.53 & 71.00 & 62.00 & 87.00 & 6.85 \\
\hline LLLL 1 [cm] & 71,53 & 71.00 & 62.00 & 87.00 & 6.85 \\
\hline RLLL 2 [cm] & 75.11 & 75.00 & 65.00 & 88.00 & 6.23 \\
\hline LLLL 2 [cm] & 75.05 & 75.00 & 65.00 & 89.00 & 6.34 \\
\hline RLLL $3[\mathrm{~cm}]$ & 64.05 & 66.00 & 54.00 & 72.50 & 5.33 \\
\hline LLLL 3 [cm] & 64.11 & 66.00 & 54.00 & 72.50 & 5.35 \\
\hline LRC RS [cm] & 27.08 & 27.00 & 22.00 & 35.00 & 2.83 \\
\hline LRC LS [cm] & 27.15 & 27.00 & 22.50 & 35.50 & 2.80 \\
\hline RLL LI 1 & 54.01 & 54.17 & 50.78 & 56.86 & 1.63 \\
\hline LLL LI 1 & 54.01 & 54.17 & 50.78 & 56.86 & 1.63 \\
\hline RLL LI 2 & 56.77 & 56.65 & 54.00 & 60.00 & 1.66 \\
\hline LLL LI 2 & 56.72 & 56.91 & 53.90 & 60.00 & 1.70 \\
\hline RLL LI 3 & 48.42 & 48.53 & 45.22 & 53.72 & 2.04 \\
\hline LLL LI 3 & 48.47 & 48.41 & 45.31 & 54.55 & 2.07 \\
\hline MI RLL 1 & 37.96 & 37.90 & 31.71 & 45.51 & 3.26 \\
\hline MI LLL 1 & 38.05 & 37.68 & 31.71 & 45.51 & 3.12 \\
\hline MI RLL 2 & 36.11 & 35.98 & 29.89 & 43.83 & 3.02 \\
\hline MI LLL 2 & 36.22 & 36.30 & 29.89 & 43.29 & 2.80 \\
\hline MI RLL 3 & 42.37 & 42.14 & 33.85 & 52.21 & 3.74 \\
\hline MI LLL 3 & 42.42 & 41.94 & 34.09 & 51.45 & 3.61 \\
\hline TUG result [s] & 7.99 & 7.84 & 5.88 & 12.31 & 1.46 \\
\hline
\end{tabular}

BH - body height, LLL - lower limb length, RLLL - right lower limb length, LLLL - left lower limb length, LRC S - largest resting circumference of shin, $L R C R S$ - largest resting circumference of right shin, LRC LS - largest resting circumference of left shin, LL LI - Lower Limb Length Index, RLL LI - Right Lower Limb Length Index, LLL LI - Left Lower Limb Length Index, MI LL - Muscle Index of Lower Limb, MI RLL - Muscle Index of Right Lower Limb, MI LLL - Muscle Index of Left Lower Limb, 1 - (B-sy) value or indicator calculated using (B-sy), 2 - (B-is) value or indicator calculated using (B-is), 3 - (B-tro) value or indicator calculated using (B-tro), TUG - Test Timed Up and Go, $\bar{x}$ - arithmetic average, Me - median, Min. - minimum value, Max. - maximum value, SD - standard deviation. 
Rzeszow. The subjects were from 7 to 12 years old The average age of the examined group was $8.58 \pm 1.20$ years (Table $1 \mathrm{~A})$. The group consisted of 15 (48.39\%) girls and $16(51.61 \%)$ boys (Table $1 \mathrm{~B}$ ).

The study was started with measurements of body height (B-v), symphysion (B-sy), iliospinale (B-is), trochanterion (B-tro), and the largest circumference of the lower leg at rest (sur), carried out in accordance with the international methodology described by Malinowski, Bożiłów [1]. The length of the lower limbs was characterised by three different measurements. The odd measurement (B-sy) was assigned to the right and left lower limb (RLLL 1, LLLL 1), and the even measurement (B-is) was assigned to the right and left lower limb (RLLL 2, LLLL 2) (B-tro) (RLLL 3, LLLL 3). For each of the measurements of the length of the lower limbs, the corresponding ratios of the length and muscularity of the lower limbs were calculated - Table 1 C [1]. The nomenclature of the abbreviations is explained in Tables 1-3. Next, TUG was carried out in accordance with the commonly used methodology [23, 24]. Each child made two test attempts, the result of which was the arithmetic mean of the times the examined child obtained. Running was forbidden. Children were often motivated in words.

\section{Statistical analysis}

A variable defined by the nominal scale (gender) was presented giving the frequency (\%) of individual categories in the analysed group. For the rest of the variables, the arithmetic mean $(\bar{x})$, standard deviation (s), and median (Me) were calculated, and the maximum (max.) and minimum (min.) were given. Compliance with the normal distribution was tested by the Shapiro-Wilk test. Statistical hypotheses were verified using nonparametric methods: Mann-Whitney $U$ test and Spearman's rank correlation coefficient. A significance level of $\alpha=0.05$ was assumed. The condition for recognising the results as statistically significant was the test probability $\mathrm{p}$ satisfying the inequality $p<0.05$. The analysis was carried out in the Statistica version 10.0 program of StatSoft Polska.

\section{Results}

Table $1 \mathrm{D}$ presents the characteristics of the parameters tested. The verification of statistical hypotheses was preceded by checking the assumptions regarding the use of parametric methods in calculations using the Shapiro-Wilk test. Statistically significant dependencies were obtained for age and TUG score, which means that the assumption of distribution normality was not met (Table $2 \mathrm{~A}$ ). Due to the fact that the key dependent variable did not have a normal distribution, hypothesis verification was carried out by nonparametric methods (Spearman's rank correlation, Mann-Whitney $U$ test).

There is no statistically significant relationship between the length of the lower limbs and the TUG score $(p>0.05)$. The analysis does not provide grounds for hypotheses about the relationship between the lower limb length index, the lower limb muscularity index, and the TUG result - statistically insignificant results were obtained $(p>0.05)$ (Table $2 \mathrm{~B})$.

The next step was to check whether there is a relationship between sex and age and anthropometric parameters: length of the lower limbs, and the index of length and muscularity of the lower limbs. Only the relationship between sex and length of lower limbs ((B-sy), (B-is)) is close to the limit of statistical significance $(p=0.045-0.060)$. Attention is drawn to slightly higher values of the length of the lower limbs in the examined boys (Table $3 \mathrm{~A}$ ). No statistical significance was found between the index of the length and muscularity of the lower limbs and gender (Table 3 A). A statistically significant relationship was found between the length of the lower limbs and age $(p<$ $0.001)$. These are strong dependencies with a positive sign $(R=0.61-0.75)$ (Table $3 \mathrm{~B})$. No statistical significance was found between the index of the length and muscularity of the lower limbs and age (Table $3 \mathrm{~B}$ ).

\section{Discussion}

Today, many researchers are involved in observation of human development and collecting information on its quantitative and qualitative features. As a result, anthropometric measurements are made and the ratio indicators are analysed, thus discovering new relationships that take place in the human body [28]. However, there are few publications on the impact of specific anthropometric parameters on the results of functional tests. If they appear, they mostly concern sick people suffering from chronic diseases, such as cerebral palsy $[22,27]$. Therefore, in order to avoid duplication of the research of other authors, and to achieve the purpose of the above work, it was decided to cover a group of healthy people and analyse the impact of their anthropometric features on the final result of the popular functional fitness test - TUG. It is worth mentioning that this test is sporadically used in paediatric practice. Until 2005, only a few publications appeared about its use. These were Pakistani, Australian, Indonesian, and Filipino studies [27]. There are also no normative values for children, including gender and age. This fact hinders the assessment of physical fitness of sick children. The presented pilot study also emphasises the need to create a table of standards for TUG.

Analysing the results of even anthropometric measurements and calculated ratio indices, it is observed that most of the values are different for the left and right side of the body. This is undoubtedly the result of human physiological asymmetry, which many authors mention in their works [6, 29]. In the literature on the subject, tables of norms can be found taking into account age and sex for such parameters as the height of symphysion (B-sy) or the limb length index 
Table 2. Results of the study - part one

\begin{tabular}{|lcc|}
\hline \multicolumn{3}{|l|}{ A. Test results of normality of variable distributions } \\
(Shapiro-Wilk test) & \multicolumn{2}{l|}{} \\
\hline Variable & 0.89 & P-value \\
Age & 0.96 & 0.215 \\
RLLL 1 [cm] & 0.96 & 0.215 \\
LLLL 1 [cm] & 0.96 & 0.375 \\
RLLL 2 [cm] & 0.96 & 0.426 \\
LLLL 2 [cm] & 0.94 & 0.087 \\
RLLL 3 [cm] & 0.93 & 0.049 \\
LLLL 3 [cm] & 0.98 & 0.750 \\
RLL LI 1 & 0.98 & 0.750 \\
LLL LI 1 & 0.97 & 0.427 \\
RLL LI 2 & 0.97 & 0.393 \\
LLL LI 2 & 0.93 & 0.056 \\
RLL LI 3 & 0.91 & 0.012 \\
LLL LI 3 & 0.99 & 0.972 \\
MI RLL 1 & 0.99 & 0.957 \\
MI LLL 1 & 0.98 & 0.911 \\
MI RLL 2 & 0.99 \\
MI LLL 2 & 0.98 & 0.853 \\
MI RLL 3 & 0.99 \\
MI LLL 3 & 0.937 \\
TUG Score [s] & 0.016 \\
\hline
\end{tabular}

\begin{tabular}{|lcc|}
\hline \multicolumn{3}{l}{ B. Anthropometric parameters and the TUG result } \\
\hline Pair of variables & $R$ & $P$-value \\
TUG score [s] \& RLLL 1 [cm] & -0.07 & 0.725 \\
TUG score [s] \& LLLL 1 [cm] & -0.07 & 0.725 \\
TUG score [s] \& RLLL 2 [cm] & 0.00 & 0.992 \\
TUG score [s] \& LLLL 2 [cm] & -0.01 & 0.972 \\
TUG score [s] \& RLLL 3 [cm] & -0.01 & 0.946 \\
TUG score [s] \& LLLL 3 [cm] & -0.01 & 0.964 \\
TUG score [s] \& RLL LI 1 & 0.31 & 0.091 \\
TUG score [s] \& LLL LI 1 & 0.31 & 0.091 \\
TUG score [s] \& RLL LI 2 & $-0,16$ & 0.394 \\
TUG score [s] \& LLL LI 2 & -0.09 & 0.611 \\
TUG score [s] \& RLL LI 3 & 0.00 & 0.998 \\
TUG score [s] \& LLL LI 3 & 0.00 & 0.985 \\
TUG score [s] \& MI RLL 1 & -0.32 & 0.080 \\
TUG score [s] \& MI LLL 1 & -0.27 & 0.138 \\
TUG score [s] \& MI RLL 2 & 0.15 & 0.414 \\
TUG score [s] \& MI LLL 2 & 0.11 & 0.564 \\
TUG score [s] \& MI RLL 3 & 0.14 & 0.453 \\
TUG score [s] \& MI LLL 3 & 0.12 & 0.530 \\
\hline
\end{tabular}

TUG - Test Timed Up and Go, RLLL - right lower limb length, LLLL - left lower limb length, RLL LI - Right Lower Limb Length Index, LLL LI - Left Lower Limb Length Index, MI LL - Muscle Index of Lower Limb, MI RLL-Muscle Index of Right Lower Limb, MI LLL - Muscle Index of Left Lower Limb, 1 - (B-sy) value or indicator calculated using (B-sy), 2 - (B-is) value or indicator calculated using (B-is), 3 - (B-tro) value or indicator calculated using (B-tro), $W$-Shapiro-Wilk test statistic value, $p$ - test probability value. $R$ - Spearman $R$ test statistic value.

calculated using the height of symphysion (B-sy) and body height (B-v) [30].

The average TUG test duration was $7.99 \mathrm{~s}$. This is not a satisfactory result considering the fact that completely healthy children were examined. Observations devoted to sick children have shown that some of them presented themselves better in the TUG test, despite co-existing disorders [9]. Fifty percent of respondents needed less than $7.84 \mathrm{~s}$ to perform the prescribed mobility task. The subject who achieved the best result completed the test in just $5.88 \mathrm{~s}$. In turn, the slowest person needed as much as $12.31 \mathrm{~s}$ to perform this task. For example, the average test result in 176 Australian children was $5.9 \mathrm{~s}$ with a range of 3 to 13 s. In group of 176 children, aged 3 to 9 years, it was shown that all examined children were able to successfully complete the test. For 144 children aged 6-12 years, the average score was 6.7 s [27]. In Pakistan, 180 children aged between 5 and 13 years were exam- ined, and the average result was $5.1 \mathrm{~s}$ [31]. In studies conducted in Indonesia among 501 children between 4 and 9 years old, the average result was $6.1 \mathrm{~s}$ [32].

The analysis of mutual correlations of the variables quoted earlier gave quite unexpected results. It turned out that the TUG functional test is not affected by the length of the lower limbs as assumed. It was expected that the result would be lower in children whose lower limbs are longer. The location of the centre of gravity of the body affects balance, and thus agility and flexibility $[8,14]$.

The impact of the gender variable was not so clearly marked. The results were close to the significance limit; however, none of the values obtained exceeded it. Presumably, this is the result of a low marked sexual dimorphism among the surveyed population. School age is for some children the initial stage of appearance of the first signs of puberty, and in some these symptoms appear much later [14]. As is known, 
Table 3. Results of the study - part two

\begin{tabular}{|c|c|c|c|c|c|c|c|c|}
\hline \multicolumn{9}{|c|}{ A. Sex and anthropometric parameters ( $U$ Mann-Whitney test) } \\
\hline \multirow[t]{2}{*}{ Variable } & \multicolumn{3}{|c|}{ Girls } & \multicolumn{3}{|c|}{ Boys } & \multirow[t]{2}{*}{$U$} & \multirow[t]{2}{*}{$P$-value } \\
\hline & $\bar{x}$ & Me & SD & $\bar{x}$ & Me & SD & & \\
\hline RLLL $1[\mathrm{~cm}]$ & 68.97 & 69.00 & 5.51 & 73.94 & 73.50 & 7.27 & 70.5 & 0.053 \\
\hline LLLL $1[\mathrm{~cm}]$ & 68.97 & 69.00 & 5.51 & 73.94 & 73.50 & 7.27 & 70.5 & 0.053 \\
\hline RLLL $2[\mathrm{~cm}]$ & 72.73 & 73.00 & 5.90 & 77.34 & 77.00 & 5.84 & 69.0 & 0.045 \\
\hline LLLL 2 [cm] & 72.73 & 73.00 & 5.99 & 77.22 & 76.00 & 6.04 & 72.0 & 0.060 \\
\hline RLLL $3[\mathrm{~cm}]$ & 62.63 & 61.50 & 5.51 & 65.38 & 66.50 & 4.95 & 87.0 & 0.202 \\
\hline LLLL $3[\mathrm{~cm}]$ & 62.80 & 62.00 & 5.59 & 65.34 & 66.50 & 4.97 & 87.5 & 0.202 \\
\hline RLL LI 1 & 54.12 & 54.55 & 1.50 & 53.91 & 53.56 & 1.79 & 106.0 & 0.594 \\
\hline LLL LI 1 & 54.12 & 54.55 & 1.50 & 53.91 & 53.56 & 1.79 & 106.0 & 0.594 \\
\hline RLL LI 2 & 57.07 & 57.38 & 1.65 & 56.49 & 56.43 & 1.68 & 89.5 & 0.236 \\
\hline LLL LI 2 & 57.06 & 57.03 & 1.52 & 56.40 & 56.30 & 1.84 & 91.5 & 0.268 \\
\hline RLL LI 3 & 49.15 & 48.81 & 2.53 & 47.74 & 47.90 & 1.14 & 73.0 & 0.066 \\
\hline LLL LI 3 & 49.28 & 48.92 & 2.56 & 47.71 & 47.86 & 1.09 & 71.0 & 0.054 \\
\hline MI RLL 1 & 38.52 & 38.89 & 3.38 & 37.44 & 37.43 & 3.15 & 101.5 & 0.477 \\
\hline MI LLL 1 & 38.61 & 38.41 & 3.34 & 37.52 & 37.59 & 2.90 & 104.0 & 0.540 \\
\hline MI RLL 2 & 36.53 & 36.99 & 3.24 & 35.72 & 35.60 & 2.85 & 108.5 & 0.654 \\
\hline MI LLL 2 & 36.61 & 36.30 & 3.05 & 35.85 & 35.91 & 2.60 & 111.0 & 0.740 \\
\hline MI RLL 3 & 42.50 & 42.59 & 4.34 & 42.25 & 41.87 & 3.22 & 117.0 & 0.922 \\
\hline MI LLL 3 & 42.49 & 41.67 & 4.20 & 42.73 & 42.40 & 3.10 & 118.0 & 0.953 \\
\hline
\end{tabular}

B. Age and anthropometric parameters (Spearman $R$ test)

\begin{tabular}{lcc|}
\hline Pair of variables & $R$ & $P$-value \\
Age [years] \& RLLL 1 [cm] & 0.68 & $<0.001$ \\
Age [years] \& LLLL 1 [cm] & 0.68 & $<0.001$ \\
Age [years] \& RLLL 2 [cm] & 0.75 & $<0.001$ \\
Age [years] \& LLLL 2 [cm] & 0.75 & $<0.001$ \\
Age [years] \& RLLL 3 [cm] & 0.62 & $<0.001$ \\
Age [years] \& LLLL 3 [cm] & 0.61 & $<0.001$ \\
Age [years] \& RLL LI 1 & -0.13 & 0.473 \\
Age [years] \& LLL LI 1 & -0.13 & 0.473 \\
Age [years] \& RLL LI 2 & -0.26 & 0.162 \\
Age [years] \& LLL LI 2 & -0.23 & 0.215 \\
Age [years] \& RLL LI 3 & -0.30 & 0.101 \\
Age [years] \& LLL LI 3 & -0.33 & 0.066 \\
Age [years] \& MI RLL 1 & -0.13 & 0.494 \\
Age [years] \& MI LLL 1 & -0.11 & 0.545 \\
Age [years] \& MI RLL 2 & -0.07 & 0.725 \\
Age [years] \& MI LLL 2 & -0.06 & 0.740 \\
Age [years] \& MI RLL 3 & -0.05 & 0.802 \\
Age [years] \& MI LLL 3 & -0.02 & 0.902 \\
\hline
\end{tabular}

RLLL - right lower limb length, LLLL - left lower limb length, RLL LI - Right Lower Limb Length Index, LLL LI - Left Lower Limb Length Index, MI LL - Muscle Index of Lower Limb, MI RLL - Muscle Index of Right Lower Limb, MI LLL-Muscle Index of Left Lower Limb, $1-(B$-sy) value or indicator calculated using (B-sy), 2 - (B-is) value or indicator calculated using (B-is), 3 - (B-tro) value or indicator calculated using (B-tro), $R$ - Spearman $R$ test statistic value, $U-U$ Mann-Whitney test statistic value, $p$ - test probability value, $x$ - arithmetic average, Me - median, SD - standard deviation. 
the process of puberty is associated with morphological changes - different in girls and boys [28]. So, if the group of respondents for the needs of the above study has not yet started this stage, it is not surprising that gender does not determine differences in relation to anthropometric parameters. The relationships between age and lower limb length of children are typical. Younger children have lower limbs shorter than older ones. This relationship is closely related to human ontogenetic development and body growth processes, as Malinowski and Wolański mention in their works $[12,14]$. It should be noted that the growth processes in children with paresis resulting from damage to the central or peripheral nervous system are disturbed. An example would be the results of temporal analysis of the development of lower limb length in children operated on for myelomeningocele. The length of the lower limbs develops at a lower kinetic level compared to healthy children, also the average annual increase in this trait is lower in this group of children compared to healthy peers [33].

Studies on the motor skills of healthy and sick children have important cognitive significance [34, 35]. In order to recognise the condition of sick children, normative values should be known. Thus, this pilot study indicates the need to determine the normative values of the TUG test for children.

\section{Conclusions}

The TUG result is not differentiated by the length of the lower limbs, or by index of length and muscularity of lower limbs, but age differentiates the length of the lower limbs. There is a need to develop normative values for the TUG test results for children, taking into account such variables as age and gender. From the clinician's point of view, it is crucial to compare children with disabilities to healthy children.

\section{Conflict of interest}

The authors declare no conflict of interest.

\section{References}

1. Malinowski A, Bożiłow W. Basics of Antropometry. Methods, Techniques, Norms. PWN, Warsaw 1997.

2. Stupnicki R. Measurements and norms in anthropometry. Zesz Nauk WSKFiT 2016; 11: 13-20.

3. Drozdowski Z. Anthropology and physical culture. Prz Antrop 1986; 52: 68-74.

4. Norton K, Olds T. Measurement techniques in anthropometry. In: Anthropometrica: a textbook of body measurement for sports and health courses. Norton K, Whittingham N, Carter L, Kerr D, Gore C, Marfell-Jones M (eds). University of New South Wales Press, Sydney 1996; 29-32.

5. Ujević D, Nikolić G, Dolezal K, Szirovicza L. New anthropometric instruments. Coll Antropol 2007; 31: 1031-1038.

6. Zeyland-Malawka E, Prętkiewicz-Abacjew E. Symptoms of asymmetry in the body posture of children and adolescents - a potential threat to the disability of the musculoskeletal system and health. Now Lek 2006; 75 : 394-398.

7. Rinaldo N, Gualdi-Russo E. Anthropometric techniques. Annali Online dell'Universita di Ferrara 2015; 10: 275-289.

8. Asienkiewicz R. From studies on the relationships of somatic features and motor fitness of children from Zielona Góra. Kult Fiz 2005; 6: 119-127.

9. Nicolini-Panisson RD, Donadio MV. Timed "Up \& Go" test in children and adolescents. Rev Paul Pediatr 2013; 31: 377-383.

10. Żak S. Assessment and testing of motor fitness in physical recreation. Zesz Nauk MWSE 2010; 15: 125-135.

11. Asienkiewicz R, Wandycz A. Diversity and interdependence of somatic features and motor abilities of children living in environments with varying degrees of urbanization. Kult Fiz 2014; 2: 177-196.

12. Malinowski A. Psychomotor development of children and youth. In: Auxology. Individual Development of Man in Biomedical Approach. Popiłka E (ed.). Oficyna Wydawnicza UZ, Zielona Góra 2009; 275-277.

13. Napierała M, Krakowiak K, Pilewska W. Physical activity, recreation and health. The state of morphological features and motor skills of 8-year-old children from the School Complex in Solec Kujawski. In: The Humanistic Dimension of Physical Culture. Zasada M, Klimczyk M, Żukowska H, Muszkieta R, Cieślicka M (eds). Polskie Towarzystwo Naukowe Kultury Fizycznej UKW, Bydgoszcz 2010; 141-145.

14. Kaczmarek M, Wolański N. Biological development of man. From conception to death. PWN, Warsaw 2018.

15. Cichy B, Wilk M, Śliwiński Z. Changes in gait parameters in total hip arthroplasty patients before and after surgery. Med Sci Monit 2008; 14: 159-169.

16. Drużbicki M, Szymczyk D, Snela S, Dudek J, Chuchla M. Objective quanititative methods of gait analysis in clinical practice. Prz Med Uniw Rzesz 2009; 4: 356-362.

17. Bywalec R. Gait disturbance - one problem, different points of view. Geriatria 2018; 12: 29-34.

18. Kania E, Głowacka-Kwiecień A, Jochymczyk K, Jureczko P. Experimental studies of gait in healthy children. Aktual Probl Biomech 2008; 2: 87-92.

19. Kania E, Tejszerska D, Jureczko P, Głowacka-Kwiecień A, Jochymczyk K. Children's gait analysis - comparative research. Aktual Problem Biomech 2009; 3: 87-92.

20. Dudek J, Chuchla M, Snela S, Szymczyk D, Drużbicki M. Walking pattern disorders in children with cerebral palsy. Prz Med Uniw Rzesz 2009; 3: 317-322.

21. Błaszczyk J. Biomechanics of locomotion. Characteristics of correct gait. In: Clinical biomechanic. Dzieciątkowska A, Wiśniowiecka E, Wyszomirska F (eds.). PZWL, Warsaw 2004; 244-268.

22. Strączyńska A, Radzimińska A, Weber-Rajek M, Strojek K, Goch A. Functional assessment of children with cerebral palsy - current reports. Post Rehabil 2015; 3: 43-49.

23. Drużbicki M, Pacześniak-Jost A, Kwolek A. Clinimetric methods used in neurological rehabilitation. Prz Med Uniw Rzesz 2007; 3: 268-274.

24. Dobosiewicz AM, Chyba P, Duda G, Jankiewicz M, Puszcz K, Zmaczyńska T. Rehabilitation in Parkinson's disease. J Educ Health Sport 2017; 7: 244-264.

25. Verbecque E, Vereeck L, Boudewyns A, de Heyning PV, Hallemans A. A modified version of the Timed Up and Go Test for children who are preschoolers. Pediatr Phys Ther 2016; 28: 409-415. 
26. Beauchet O, Fantino B, Allali G, Muir SW, Montero-Odasso M, Annweiler C. Timed Up and Go Test and risk of falls in older adults: a systematic review. J Nutr Health Aging 2011; 15: 933-8.

27. Williams EN, Carroll SG, Reddihough BA, Phillips BA. Galea MP. Investigation of the timed ' $U p$ \& Go' test in children. Dev Med Child Neurol 2005; 47: 518-524.

28. Perenc L, Radochońska A. Sex dimorphism of selected anthropometric features in Rzeszów children and adolescents aged 3-18 years examined in 1978-2004. Prz Med Uniw Rzesz Inst Leków 2012; 1: 38-49.

29. Majewska J, Szczepanik M, Drużbicki M, Snela S, Rusek W, Sobota G, Nowak E, Durmała J, Bonikowski M. Assessment of relation between gait and static balance in children with cerebral palsy. Eur J Clin Exp Med 2017; 15: 24-31.

30. Perenc L, Radochońska A, Błajda J. Changes in body proportions of children and adolescents from Rzeszów during a 35-year period from 1978/79-2013/14. Eur J Clin Exp Med 2018; 16: 267-282.

31. Habib Z, Westcott S, Valvaro J. Assessment of balance abilities in Pakistani children: a cultural perspective. Ped Phys Ther 1999; 11: 73-82.

32. Takarini NT, Williams EN, Denetry L. TUG in Indonesian children. The World Confederation of Physical Therapists Congress; 2-12.06.2003 r, Barcelona, Hiszpania: https://www.wcpt.org/sites/wcpt.org/files/abstracts2003/ common/abstracts/1418.html.

33. Perenc L. Temporal analysis of the development of anthropometric features of children operated on for myelomeningocele. Prz Med Uniw Rzesz 2005; 2: 103-112.

34. Szymczyk D, Majewska J, Szczepanik M i wsp. Assessment of spatio-temporal gait parameters in the group of 9 years old healthy children. Med Rev 2016; 14: 376-381.

35. Guzik A, Drużbicki M, Perenc L, Podgórska-Bednarz J. Can an observational gait scale produce a result consistent with symmetry indexes obtained from 3-dimensional gait analysis? A concurrent validity study. J Clin Med 2020; 9: 926.

\section{Address for correspondence:}

\section{Prof. Lidia Perenc}

Institute of Health Sciences

University of Rzeszow

Rzeszow, Poland

Phone: +48 697510252

E-mail: lidiaiadam.perenc@wp.pl 